\title{
DAMPAK PEMBUANGAN LIMBAH BAHAN BERBAHAYA DAN BERACUN (B3) TERHADAP KESEJAHTERAAN SOSIAL MASYARAKAT DESA LAKARDOWO KABUPATEN MOJOKERTO
}

Yoelanda Ananta Dhevi Wardani ${ }^{1}$, Muhammad Rusli ${ }^{2}$, Ambo Upe $^{3}$

${ }^{123}$ Fakultas Ilmu Sosial dan Ilmu Politik Universitas Halu Oleo

E-mail: yolandawardani03@gmail.com, muhammadrusliunahalu@gmail.com, ambo.upe@uho.ac.id

do)

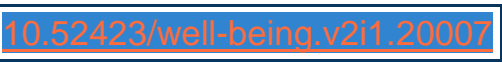

ABSTRACT

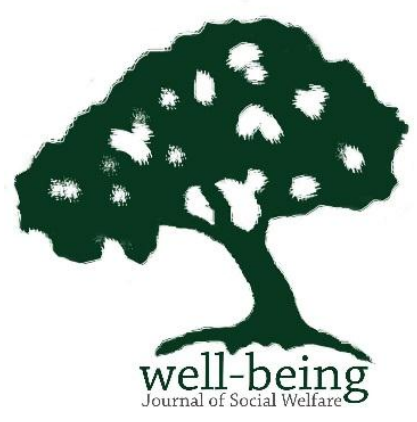

The research aims to determine the impact of hazardous and toxic waste substances (B3) disposal toward the social welfare in Lakardowo village Mojokerto. The type of this research is descriptive qualitative. The data collection that used is by observation, interview and documentation with 10 people in Lakardowo village. The result of this research is the impact of hazardous and toxic waste substances (B3) disposal toward social welfarestarting from material, social and spiritual, such as reducing the income that hit the majority society as a farmer in Lakardowo village which feel the damage in their agricultural land and increasing the cost of living for clean water. The emerge of Dermatitis or itchy disease that mostly attacks children body as a result of using well water or water sources in Lakardowo village. The rise of conflict between two camps in the society that causing the reduce of spiritual activities and also customs, which make the social welfare in Lakardowo village unfulfilled.

Keywords: Impact, Disposal, Welfare, Hazardous Waste, Society

\section{PENDAHULUAN}

Pembangunan industri merupakan salah satu upaya dari manusia untuk meningkatkan kualitas hidup, salah satu tujuan dari pembangunan industri di antaranya adalah untuk memperluas lapangan kerja, menunjang pemerataan pembangunan, meningkatkan pendapatan dan kesejahteraan masyarakat yang ada di sekitar kawasan industri (Upe, et al., 2019). Pembangunan industri memiliki kekurangan dan kelebihan salah satunya dalam kelebihan misalnya dapat menyerap tenaga kerja sekitar kawasan industri, meningkatkan kondisi sosial dan ekonomi masyarakat sekitar dan kekurangannya ialah dampak dari pembuangan limbah yang mencemari, asap pabrik yang merusak kesehatan dan berkurangnya lahan hijau di kawasan industri.

Menurut PP No.18 tahun 1999, yang dimaksud dengan limbah B3 adalah sisa suatu usaha atau kegiatan yang mengandung bahan berbahaya atau beracun yang karena sifat atau konsentrasinya dengan jumlahnya, baik secara langsung maupun tidak langsung dapat mencemarkan lingkungan hidup, kesehatan, kelangsungan hidup manusia serta makhluk hidup lain (Supriyadi, et al., 2021). Pada intinya setiap makhluk hidup yang terkena konsentrasi dan atau sifat yang dengan jumlahnya mengandung B3 dan akan membahayakan manusia, makhluk hidup dan lingkungan apapun itu jenis bahannya (Asif, et al., 2020). Pembuangan limbah B3. Sebagian dari limbah B3 yang telah diolah atau tidak dapat diolah dengan teknologi yang tersedia harus berakhir pada pembuangan (disposal). Tempat pembuangan akhir yang banyak digunakan untuk limbah B3 ialah landfill (lahan urug) (Damanhuri E, 1994: 67).

Lingkungan Desa Lakardowo Kecamatan Jetis Kabupaten Mojokerto yang kini sudah menjadi masalah besar ketika terjadinya pencemaran yang diakibatkan dari limbah lahan urug (tanah timbunan) yang dihasilkan dari industri PT. Putra Restu Ibu Abadi (PRIA) industri 
pengelolaan dan pemanfaatan limbah Bahan Berbahaya dan Beracun (B3) yang terdapat di Desa Lakardowo sejak 2010. PT. PRIA mengolah limbah B3 seperti limbah medis atau laboratorium yang akan dimusnahkan dan memanfaatkan limbah B3 sebagai bahan pembuatan batako dan pembuatan kertas low grade (kertas daur ulang) namun masih terdapatnya limbah B3 yang tidak dapat didaur ulang sehingga dimanfaatkan untuk menjadai tanah timbunan di sekitar pabrik, timbunan jalan di persawahan dan juga timbunan di rumah warga.

Warga Desa Lakardowo menuntut tentang hak kesejahteraannya akibat tercemarnya lingkungan dari limbah B3, masyarakat Desa Lakardowo mengeluhkan aktivitas dari pabrik yang menyebabkan kehidupan masyarakat terganggu dan tidak sehat dikarenakan tercemarnya lingkungan. Masyarakat Desa Lakardowo sangat menggantungkan penghasilan perekonomian dari sektor pertanahan atau sebagian besar mata pencaharian masyarakatnya adalah sebagai petani. Akibat kesewenangan dari pihak pabrik kini kebersihan lingkungan menjadi terancam, lingkungan hidup yang menjadi sumber kehidupan dan sumber kebutuhan masyarakat kini menjadi korban dari kelalaian pihak pabrik.

Keadaan masyarakat kini berubah semenjak berdirinya pabrik pengelolaan dan pemanfaatan limbah B3 PT. PRIA di lokasi Desa Lakardowo. Keberadaan PT. PRIA dinilai telah merusak lingkungan hidup sekitar wilayah Desa Lakardowo. Hal ini berdampak besar bagi lingkungan dan kesehatan masyarakat, seperti munculnya Dermatitis atau penyakit gatalgatal iritasi pada kulit yang dialami oleh masyarakat Desa Lakardowo. Sekitar 60\% air sumur di Desa Lakardowo telah tercemar dari limbah B3 dan mengakibatkan penyakit dermatitis atau iritasi kulit yang diderita lebih dari 432 warga Desa Lakardowo selama bulan November 2016 hingga Januari 2017. Mayoritas warga yang terdampak dari pencemaran air yang mengakibatkan iritasi pada kulit atau dermatitis dari limbah B3 adalah anak-anak dan perempuan.

Mengacu pada Menurut UU No. 11 Tahun 2009 tentang kesejahteraan sosial menyatakan bahwa kesejahteraan sosial adalah kondisi terpenuhinya kebutuhan material, spiritual, dan sosial warga negara agar dapat hidup layak dan mampu mengembangkan diri, sehingga dapat melaksanakan fungsi sosialnya. Dalam hal ini masyarakat Desa Lakardowo menuntut hak kesejahteraan hidup terhadap penolakan keberadaan pabrik yang mencamari lingkungan akibat lahan urug (tanah timbunan) dari PT.PRIA. Masyarakat menuntut hak atas air bersih layak konsumsi yang sejak beberapa tahun lalu tercemar oleh limbah B3 dari PT. PRIA.

Mayoritas masyarakat Desa Lakardowo sebagai petani berupa padi, jagung dan cabai hasil panen atau kualitas tanaman kini merosot akibat tercemarnya tanah dengan limbah B3 dari PT. PRIA. Dengan beroperasionalnya PT PRIA juga mengakibatkan menurunnya kualitas udara di lingkungan Desa Lakardowo, dikarenakan banyaknya mobilitas transportasi pengangkut limbah dan alatalat berat lainnya yang digunakan oleh PT PRIA untuk mendukung beroperasinya PT PRIA, mobilitas transportasi penganggut limbah dan alat-alat berat lainnya dan juga asap hitam dari hasil pembakaran berupa alat medis dan limbah yang memunculkan aroma tidak sedap. Munculah beberapa fenomena atau suatu kejadian yang ada dan menandakan ketidakharmonisan dalam bidang keagamaan antar kubu, sehingga menimbulkan perpecahan antar masyarakat pro dan kontra yang menyebabkan kegiatan kerohanian di Desa Lakardowo terganggu dan bahkan sudah tidak lagi ada. Penelitian 
ini bertujuan untuk mengetahui dampak pembuangan limbah Bahan Berbahaya dan Beracun (B3) terhadap kesejahteraan sosial masyarakat Desa Lakardowo Kabupaten Mojokerto.

\section{METODE PENELITIAN}

Jenis penelitian ini adalah jenis penelitian lapangan yaitu jenis penelitian yang bertujuan untuk mendapatkan data yang diperlukan dengan dilakukan secara langsung di lapangan. Jenis penelitian ini adalah penelitian kualitatif yaitu penelitian yang menghasilkan data deskriptif berupa ucapan, tulisan dan perilaku yang dapat diamati dari orang tua atau subjek tertentu (Upe, 2016). Sebagaimana dalam penelitian ini, penulis meneliti tentang dampak pembuangan limbah bahan berbahaya dan beracun (B3) terhadap kesejahteraan sosial masyarakat Desa Lakardowo Kabupaten Mojokerto. Informan dalam penelitian adalah beberapa warga yang dapat mewakili seluruh warga desa Lakardowo antara lain Tokoh Agama sekaligus tetua masyarakat lakardowo, Aktivis dari organisasi Pendhowo Bangkit, Kepala Desa Lakardowo dan masyarakat yang terdampak dari pembuangan limbah Bahan Berbahaya dan Beracun (B3). Sumber data yang di gunakan dalam penelitian ini adalah data primer yang diperoleh dari masyarakat Desa Lakardowo dan data sekunder berupa informasi untuk menunjang kematangan penelitian, seperti hasil penelitian, buku, jurnal, dan artikel yang relevan dengan penelitian ini.Dalam penelitian untuk mendapatkan data yang di perlukan dalam penelitian ini, penulis menggunakan beberapa teknik pengumpulan data. Tujuannya agar di peroleh data yang obyektif, Adapun teknik pengumpulan data tersebut antara lain:

a. Wawancara

Wawancara dalam penelitian ini adalah dengan memberikan beberapa pertanyaan-pertanyaan secara lisan kepada informan yang relevan dengan penelitian. Informan akan memberikan data yang dibutuhkan dalam penelitian ini yaitu data yang berkaitan dampak pembuangan limbah bahan berbahaya dan beracun (B3) terhadap kesejahteraan sosial masyarakat Desa Lakardowo.

b. Observasi

Metode ini digunakan untuk menghimpun data yang berkenaan dengan perilaku manusia, proses kerja dan responden yang diamati tidak terlalu besar. Melalui metode observasi ini penulis dapat melakukan pengamatan secara langsung terhadap bagaimana dampak pembuangan limbah bahan berbahaya dan beracun (B3) terhadap kesejahteraan sosial masyarakat Desa Lakardowo.

c. Dokumentasi

Data dalam bentuk dokumentasi dimaksudkan untuk mendukung data lapangan. Dokumentasi dilakukan untuk memberikan bukti penelitian yang berupa gambar-gambar yang dibutuhkan oleh peneliti demi kelengkapan penelitian yang bertujuan untuk menjanwab permasalahan dalam penelitian ini. Pengambilan gambar dilakukan saat wawancara dan saat melakukan penelitian langsung di lokasi penelitian.

Analisis Data kualitatif yang diperoleh melalui wawancara disajikan dalam bentuk kalimat atau naratif. Pengumpulan data (data collection) adalah pengumpulan data dengan menggunakan instrumen.

1. Reduksi data Reduksi dapat diartikan proses pemilihan, pemusatan perhatian yang menyederhanakan, pengabstrakan dan transformasi data kasar yang muncul dari catatan tertulis di lapangan.

2. Display data atau penyajian data merupakan alur penting yang kedua dari kegiatan sebuah penelitian. Suatu penyajian data merupakan kumpulan informasi tersusun yang memberikan 
kemungkinan adanya penarikan kesimpulan dan pengambilan tindakan.

3. Verifikasi data. Langkah ketiga dalam analisis data kualitatif adalah penarikan kesimpulan dan verifikasi. Kesimpulan dalam penelitian kualitatif adalah merupakan temuan baru yang sebelumnya belum pernah ada.

\section{HASIL DAN PEMBAHASAN}

Dampak Pembuangan Limbah Bahan Berbahaya dan Beracun (B3) Terhadap Kesejahteraan Sosial Masyarakat Desa lakardowo

Dampak yang terjadi di Desa Lakardowo tercemarnya lingkungan dari limbah B3, masyarakat Desa Lakardowo mengeluhkan aktivitas dari pabrik yang menyebabkan kehidupan masyarakat terganggu dan tidak sehat dikarenakan tercemarnya lingkungan. Masyarakat Desa Lakardowo sangat menggantungkan penghasilan perekonomian dari sektor pertanahan atau sebagian besar mata pencaharian masyarakatnya adalah sebagai petani. Akibat kesewenangan dari pihak pabrik kini lingkungan menjadi terancam, lingkungan hidup yang menjadi sumber kehidupan dan sumber kebutuhan masyarakat kini tercemar oleh limbah B3.

Masyarakat Desa Lakardowo merasakan dampak yang diakibatkan dari limbah B3 yang dihasilkan oleh pabrik, mulai dari menurunnya kualitas udara di sekitar Desa Lakardowo karena mobilitas dan aktivitas dari pabrik, perpecahan antar masyarakat yang menimbulkan konflik sosial dan tercemarnya air sumur sekitar 60\% air sumur di Desa Lakardowo telah tercemar limbah B3 yang mengakibatkan penyakit dermatitis atau iritasi kulit yang diderita lebih dari 432 warga Desa Lakardowo selama bulan November 2016 hingga Januari 2017. Mayoritas warga yang terdampak pencemaran air dari limbah B3 adalah anak-anak dan perempuan, sehingga menyebabkan munculnya berbagai dampak dalam kehidupan masyarakat meliputi dampak materil, sosial, dan spiritual untuk lebih lengkapnya mengkaji ketiga dampak tersebut diuraikan sebagai berikut :

\section{Dampak Materil Pembuangan Limbah Bahan Berbahaya dan Beracun (B3)}

Dampak materil yang dirasakan langsung oleh masyarakat Desa lakardowo berupa berbagai permasalahan yang muncul akibat dari dampak limbah bahan berbahaya dan beracun (B3) yang kini dirasakan mulai dari munurunnya tingkat pendapatan dan penghasilan dari pertanian yang mayoritas penduduk mata pencahariannya sebagai petani, pengeluaran biaya untuk berobat ke dokter akibat dari limbah yang menyebabkan munculnya dermatitis atau gatal-gatal yang rata-rata dialami anak-anak dan wanita kemudian juga bertambahnya biaya rumah tangga yang harus membeli air bersih untuk dikonsumsi karena air sumur di Desa Lakardowo sudah tidak memenuhi baku mutu kualitas air. Dan juga masyarakat Desa Lakardowo mengeluhkan gangguan pernapasan akibat kepulan asap yang berbau seperti obat-obatan dan alat medis dari proses pembakaran limbah bahan berbahaya dan beracun (B3) dari pabrik sejak tahun 2016. Berikut dampak materil dari limbah B3 terhadap masyarakat Desa Lakardowo :

a. Berkurangnya pendapatan masyarakat

Masyarakat Desa Lakardowo merasakan dampak dari limbah B3 akibatnya rusaknya lingkungan sehingga menyebabkan menurunnya pendapatan masyarakat yang mayoritas bekerja sebagai petani dan mata pencaharian utama dalam bidang pertanian seperti tanaman padi, jagung, cabai dan lainnya, kini hasil panen menurun akibat tercemarnya tanah dan air bawah tanah di Desa Lakardowo.

Dengan beroperasionalnya pabrik juga mengakibatkan menurunnya kualitas 
udara di lingkungan Desa Lakardowo, hal tersebut dimungkinkan terjadi dikarenakan banyak nya mobilitas transportasi penganggut limbah dan alat-alat berat lainnya yang digunakan oleh pabrik untuk mendukung beroperasinya pabrik, tanaman yang rusak karena mobilitas transportasi dari pabrik juga membuat tanaman disekitar jalan raya tidak dapat dimanfaatkan untuk konsumsi ternak karena tanaman kering berdebu dan rusak sehingga masyarakat yang dulunya memanfaatkan tanaman liar seperti rumput yang tumbuh di samping-samping jalan raya kini harus mencari ditempat lain atau membeli pakan untuk ternak mereka ditempat lain. Asap hitam dari hasil pembakaran berupa alat medis dan limbah yang memunculkan aroma tidak sedap dan sangat mengganggu aktivitas masyarakat di lingkungan pabrik yang jaraknya tidak jauh dari pemukiman warga, berikut adalah gambar yang menunjukan asap hitam yang terlihat mengepul diatas cerobong pabrik yang berasal dari hasil pembakaran limbah B3 seperti limbah medis dan obat-obatan.

b. Bertambahnya kebutuhan untuk air bersih

Tercemarnya air bawah tanah karena limbah B3 mengakibatkan air tidak bisa lagi dikonsumsi oleh masyarakat Desa Lakardowo, air cennderung keruh, berbau tidak sedap bahkan sudah berubah warna sehingga masyarkat tidak menggunakan air tersebut sebagai konsumsi namun masih bisa digunakan untuk mencuci namun untuk konsumsi masyarakat Desa Lakardowo menggunakan air yang harus dibeli sehingga menambahkan biaya untuk kehidupan masyarakat bertambah untuk membeli kebutuhan air bersih.

\section{Dampak Sosial Pembuangan Limbah Bahan Berbahaya dan Beracun (B3)}

Dampak yang terjadi di masyarakat dapat bersumber dari memudarnya nilainilai sosial masyarakat, merosotnya kekuatan mengikat sebagai norma-norma sosial sehingga menimbulkan bentuk perilaku menyimpang serta ketergantungan masyarakat pada pihak lain sebagai akibat dari sistem pembangunan yang kurang porposional yang bersifat fisik, dampak dari proses pembangunan antara lain berupa masalah yang berkaitan dengan pencemaran dan kelestarian lingkungan memberikan dampak dalam kehidupan masyarakat munculnya disharmonisasi dalam suatu kelompok masyarakat.

Suatu keadaan dikatakan disharmonisasi adalah keadaan yang biasanya mencerminkan suatu kondisi dalam situasi yang terjadi dalam sebuah kelompok dan kelompok ini adalah sekumpulan manusia atau masyarakat. Disharmonisasi selalu berkaitan dengan keadaan sebuah rumah tangga atau keluarga. Jadi apabila didalamnya (keluarga/rumah tangga) terdapat sebuah ketidakbahagian, maka keluarga tersebut dinyatakan disharmonisasi.

Disharmonisasi adalah suatu bentuk tidak terjadinya keselarasan secara keseluruhan yang dianggap mempunyai nilai negatif dengan beberapa aspek penilaian. Berdasarkan uraian tersebut, maka dapat dinyatakan bahwa disharmonisasi adalah suatu keadaan atau kondisi yang terlihat tidak bahagia dalam suatu kumpulan manusia dan biasanya itu terdapat dalam suatu keluarga.

Munculnnya disharmonisasi dalam kelompok masyarakat menyebabkan masyarakat menjadi terpecah dan memunculkan konflik antar masyarakat dan juga terhadap keluarga ataupun kerabat terdekat. Suatu hubungan sosial antar masyarakat akan menghasilkan sebuah konflik. Masyarakat terbentuk dari hubungan sosial dan akan selalu adanya konflik antara masyarakat dengan masyarakat yang terlibat dalam suatu hubungan sosial. Dimana terdapat suatu perbedaan maka akan munculah sebuah 
konflik di tengah masyarakat. Dengan adanya pembuangan limbah bahan berbahaya dan beracun (B3) di lingkungan Desa Lakardowo oleh pihak perusahaan pengelolaan limbah B3 sehingga terjadilah pencemaran lingkungan dari limbah B3 menyebabkan konflik itu muncul di Desa Lakardowo antara masyarakat dengan pihak pabrik dan juga muncullah konflik antar masayrakat.

Keadaan konflik yang berkepanjangan di Desa Lakardowo menyebabkan perpecahan antar masyarakat menjadi kelompok antara pro dan kontra dimana kedua kelompok memiliki pendapat berbeda terhadap pabrik, masyarakat yang pro terhadap pabrik akan mendukung pabrik dan masyarakat yang kontra terhadap pabrik menolak adanya pabrik. Konflik ini muncul akibat adanya kekecewaan terhadap tuntutan yang terjadi dalam hubungan dan dari perkiraan kemungkinan keuntungan bagi partisipan dengan obyek yang dianggap telah mengecewakan. Dengan adanya tuntutan-tuntutan yang belum sepenuhnya dipenuhi oleh pihak pabrik yang menyebabkan konflik menjadi berkepanjangan. Konflik ini timbul karena adanya tuntutan atas perubahan dalam masyarakat. Perubahan yang dimaksud dalam konflik ini merupakan perubahan keadaan lingkungan yang merugikan masyarakat.

\section{Dampak Spiritual Pembuangan Limbah Bahan Berbahaya dan Beracun (B3)}

UU kesejahteraan sosial 1974 menyebut istilah spiritual secara bergantian dengan rohaniah, sebagaimana istilah material yang tampak disepadankan dengan istilah jasmaniah dan juga istilah lahir bathin yang disebut beriringan. Dengan demikian, dapat disimpulkan bahwa aspek spiritual dalam UU Kessos yang baru merujuk atau disamakan dengan istilah rohaniah. Begitu pula dengan dampak spiritual yang dirasakan oleh masyarakat Desa Lakardowo akibat dari pembuangan limbah bahan berbahaya dan beracun (B3) terhadap masyarakat mulai dari pecahnya agama islam di wilayah Desa Lakardowo, dimana warga yang terdampak tidak bergabung atau berjamaah di wilayah masjid atau mushola dari pihak yang bekerja di pabrik ataupun yang memihak pada pabrik.

a. Berkurangnya partisipasi dalam kegiatan kerohanian

beberapa fenomena atau suatu kejadian yang ada dan menandakan ketidakharmonisan dalam bidang keagamaan antar kubu, yaitu absent nya atau ketidakhadirannya warga yang pro untuk memenuhi undangan dalam kegiatan keagamaan yang dilaksanakan kelompok kontra, dan sebaliknya, seperti Diba'an (pengajian) pernikahan, kemudian dilarangnya kelompok pro untuk menjadi anggota kepengurusan majlis ta'lim dan ta'mir masjid, bahkan ketika ada kelompok pro yang meninggal maka kelompok kontra enggan untuk datang dan ta'ziyah atau memberikan ucapan bela sungkawa kemudian untuk kelompok yang pro dengan PT PRIA, maka diwajibkan untuk melepaskan hak nya untuk mengisi khutbah dimasjid, maka kyai yang merasa dikeluarkan dari kelompok akhirnya membuat jamaah atau memetakkan tersendiri sehingga terjadilah fenomena kyai pro dan kontra di Desa Lakardowo. b. Mengalami transformasi adat istiadat Adat istiadat merupakan hal yang dilakukan berulang-ulang lalu menjadi suatu kebiasaan yang tetap dan dihormati orang, maka kebiasaan itu menjadi adat. Adat merupakan kebiasaan-kebiasaan yang tumbuh dan terbentuk dari suatu masyarakat atau daerah yang dijunjung serta di patuhi masyarakat pendukungnya. Adat istiadat merupakan kebiasaan sosial yang sejak lama ada dalam masyarakat dengan maksud mengatur tata tertib. Ada 
pula yang mengikat norma dan kelakuan di dalam masyarakat, sehingga dalam malakukan suatu tindakan mereka akan memikirkan dampak akibat dari berbuatannya atau sekumpulan tata kelakuan yang paling tinggi kedudukannyakarena bersifat kekal dan terintegrasi sangat kuat terhadap masyarakat yang memilikinya. Namun di Desa Lakardowo kini sudah mengalami transformasi adat istiadat, yang merubah struktur kaidah-kaidah kebudayaan menjadi kaidah-kaidah lain dengan menambah, mengurangi, dan menata kembali unsur-unsur adat istiadatnya. Berkurangnya kegiatan adat istiadat di Desa Lakardowo akibat dari perpecahan masyarakat pro dan kontra terhadap pabrik seperti hilangnya kegiatan kenduren atau kegiatan mengundang masyarakat setempat untuk mengucap rasa syukur kepada Tuhan YME, kegiatan upacara pernikahan, kegiatan maulid.

\section{KESIMPULAN}

Berdasarkan hasil penelitian dan pembahasan yang telah dilakukan tentang dampak pembuangan limbah bahan berbahaya dan beracun (B3) terhadap kesejahteraan masyarakat Desa Lakardowo maka dapat disimpulkan sebagai berikut :

Penelitian ini memiiliki rumusan masalah yaitu bagaimana dampak pembuangan limbah B3 di Desa Lakardowo, Kabupaten Mojokerto mulai dari dampak materil, sosial dan spiritual. Penelitian ini menggunakan metode penelitian kualitatif dengan triangulasi sebagai validasi data. Subjek penelitian ini adalah warga Desa Lakardowo, kabupaten Mojokerto. Penelitian ini menghasilkan temuan yaitu Aktivitas industrialisasi PT. PRIA yang melakukan pembuangan Limbah B3 memiliki banyak dampak pada masyarakat seperti terjadinya kerusakan lingkungan, menurunnya kesehatan masyarakat, menurunnya penghasilan masyarakat dan munculah disharmonisasi sosial sehingga tidak terpenuhinya kesejahteraan sosial masyarakat Desa Lakardowo, seperti tidak terpenuhinya kebutuhan materil, spiritual dan sosial masyarakat. Dimana kesejahteraan sosial mengacu pada UU No. 11 Tahun 2009 tentang kesejahteraan sosial yang menyatakan bahwa kesejahteraan sosial adalah kondisi terpenuhinya kebutuhan material, spiritual, dan sosial warga negara agar dapat hidup layak dan mampu mengembangkan diri sehingga dapat melaksanakan fungsi sosialnya.

\section{DAFTAR PUSTAKA}

Adi, Isbandi Rukminto. 2013. Kesejahteraan Sosial (Pekerjaan Sosial, Pembangunan Sosial, dan Kajian Pembangunan). Jakarta: Rajawali Pers.

Asif, M., Bushra Sharf, \& Saqaina Anwar. (2020). Effect of Heavy Metals Emissions on Ecosystem of Pakistan. Indonesian Journal of Social and Environmental Issues (IJSEI), 1(3), 160-173.

Asnawi. (2020, Oktober 25). mongabay.id. Nasib Warga Lakardowo, Satu Dasawarsa Hidup dengan Limbah Berbahaya: https://www.mongabay.co.id/2020/10/ 25/nasib-warga-lakardowo-satudasawarsa-hidup-dengan-limbahberbahaya-1/

Azmi, A. I., Alisa, A. N., \& Oktavia, F. Strategi Gerakan Perempuan (Green Woman) Dalam Melawan Pencemaran Lingkungan Oleh Industri Pengelolaan Limbah B3 Di Desa Lakardowo Kabupaten Mojokerto. Jurnal Neo Societal, 6(1), 66-77.

Damanhuri, E. 2010. Diktat Pengelolaan Sampah. Teknik Lingkungan Institut

Fahrudin, Adi. 2012. Pengantar Kesejahteraan Sosial. Bandung: PT Refika Aditama 
Moleong, Lexy J. (2012). Metode Penelitian Kualitatif. Bandung: PT Remaja Rosdakarya.

Peraturan Pemerintah No. 85 Tahun 1999 Tentang: Perubahan Atas Peraturan Pemerintah No. 18 Tahun 1999 Tentang Pengelolaan Limbah Bahan Berbahaya Dan Beracun. Kementrian Lingkungan Hidup, Jakarta.

Riyanto., 2013. Limbah Bahan Berbahaya dan Beracun. Yogyakarta: Deepublish

Sari, D. K. (2017). Strategi Mobilisasi Gerakan Masyarakat Dalam Penutupan Industri Pengelolaan Limbah B3 Di Desa Lakardowo Kabupaten Mojokerto. Jurnal Politik Indonesia, 2(1).

Sidik, A. A., \& Damanhuri, E. (2012). Studi Pengelolaan Limbah B3 (Bahan Berbahaya Dan Beracun) Laboratorium Laboratorium Di ITB. Jurnal Teknik Lingkungan, 18(1), 1210.

Skripsi Muhaimin: Konflik industrialisasi di desa lakardowo kabupaten mojokerto dalam perspektif politi lingkungan. (Surabaya: Universitas Islam Ampel Surabaya 2018).

Sudrajat, A. (2008). Teori-teori Motivasi. Tersedia juga dalam http://akhmadsudrajat. wordpress. com/2008/02/06/teori-teori-motivasi/

Sugiyono. (2012). Metode Penelitian Pendidikan Pendekatan Kualitatif, Kuantitatif, dan Research and Development. Bandung: Alfabeta.Teknologi Bandung (ITB): Bandung.

Supriyadi, A. P., Adelia Rachmaniar, Aris Mustriadhi, \& Hasyimi Pradana. (2021). Novel Renewable Energy as Resources for Environmentally Friendly National Energy Security: The Existence and the Readiness of the Regulatory Framework. Indonesian Journal of Social and Environmental Issues (IJSEI), 2(1), 59-67.
Upe, A., Salman, D., Agustang, A. (2019). The Effects of the Exploitation of Natural Resources towards Risk Society Construction in Southeast Sulawesi Province, Indonesia. Journal of Degraded and Mining Lands Management, 6(2).

Upe, Ambo. (2016). Metode Penelitian Sosial: Filosofi dan Desain Praktis. Kendari: Literacy Institute. 